\section{CLIL\& Drama: A strategy to Develop Students' Speaking Skills.}

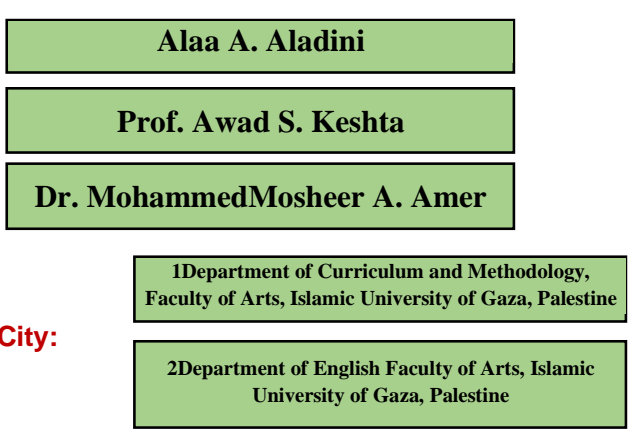

* Corresponding author:

E-mail address: a.udaini@unrwa.org

\title{
https://doi.org/10.33976/IUGJEPS.29.2/2021/23
}

\begin{abstract}
:
This study aimed at investigating the effect of Content and Language Integrated Learning (CLIL) and drama on developing 9th graders' English speaking skills. Among the speaking skills, the focus of this study is on describing sequence of events based on visual input; expressing personal feelings, emotions and the like; responding to direct questions, instructions, suggestions, offers, visual input and the like and responding to referential, inferential and factual questions. A pre-post achievement test was conducted on a sample of (68) ninth graders who were randomly chosen from Al- Mamounia preparatory UNRWA school in Gaza Strip to represent the study community. Using a checklist to identify the most important speaking skills, the sample was divided into two equal groups (experimental and control). The findings revealed that the program based on CLIL and Drama was effective to improve the $9^{\text {th }}$ graders' speaking skills. Accordingly, the researchers recommend the Palestinian EFL teachers to dramatize the CLIL as a tool of enhancing students' speaking skills.
\end{abstract}

Key words: Suggested Program, CLIL, Drama, strategy, EFL, Speaking skills.

التعلم المدمج للغة والمحتوى والدراما: استراتيجية مقترحة لتطوير مهارات التحدث في اللغة الإنجليزية

(الملخص: تهدف هذه الدراسة إلى التحقق من أثر برنامج مقترح قائم على التعلم المدمج والمحتوى والدراما، وأثره على تنمية مهارات التحدث في اللغة الإنجليزية، وهي: وصف أحداث متسلسلة مبنية على صور، والتعبير عن العواطف والمشاعر الذاتية ، والاستجابة على أسئلة مباشرة وتعليمات واقتراحات وعروض، والاستجابة على أسئلة حقائق واستنتاجات . لقد طُبقت الدراسة على عينة عشوائية ممثلة مكونة من (68) طالبة من طلاب الصف التاسع من مدرسة بنات

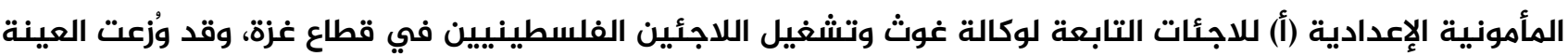
على مجموعتين متكافئتين. استخدم الباحث أداتين لهذه الدراسة وهي قائمة فحص للمعلمين لكي يحددوا أهم مهارات التحدث للصف التاسع واختبار تحصيل قبلي وبعدي. وتوصل الباحثون من خلال تحليل نتائج هذه الدراسة إلى أن البرنامج المقترح كان فعالاً في تحسين مهارات التحدث للصف التاسع الأساسي. في ضوء هذه النتائج، أوصى

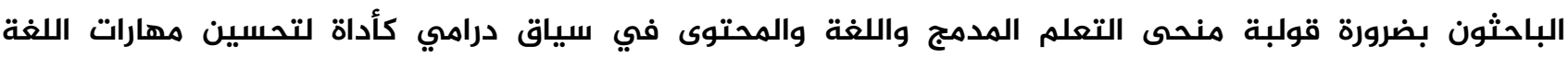




\section{Introduction:}

English is used as a common language for mostly the whole world nowadays. It's a global language which is widely used in all the fields as scientific research, education, business, the internet, travel and tourism, media and newspapers, software, medicine, engineering, information and technology, entertainment, banking (Rao, 2019; Sabina, 2018; Sadiku, 2015; Torky, 2006 and Keshta, 2000). In this modern world, communication skills play a basic role and they are considered as key to success in all fields. English language skills are indispensable tools for daily communication with most of the outside world. Sabina (2018) stated that speaking is the most important skill. Yet, many learners find it as a frustrating skill to be learnt. People spend great deal of their time interacting with more people in many daily life situations and, each of these situations requires a different register to be used according to the formality of the moment. Speakers use these registers to speak for many reasons.

Language users vary in their degree of linguistic accuracy. In the production skills (speaking and writing), accuracy includes a measure of the suitability of the message with regard to the sociocultural context, the acceptability of the message to the listener. English for Palestine includes speaking skills which aim to aid learners to communicate effectively with speakers of English in different social and academic environments. Thus, learners can communicate appropriately in various settings using the target language. The Palestinian curriculum confirms that the four English language skills should be taught in an interactive method. Speaking is one of the main skills of teaching English language that aims to get students speak comfortably and intelligibly with accurate pronunciation (English Language Curriculum, henceforth (ELC) Palestinian Ministry of Education, 2015).

Speaking is challenging skill to teach and to learn; therefore, there are some studies which suggested how to improve speaking skills in an EFL classroom. Singh, Ja'afar, Abdullah, Mostafa, and Zamri (2018) suggested Flipped Classroom as an approach that improves speaking ability among Technical and Vocational Engineering and Training institutes in Malaysia. In the same concern, Wang (2017) suggested cooperative learning as a student-centered instructional approach that has the potential to encourage more communicative interactions among students and maximize the improvement of each student's learning process. Moreover, Ozturk, Gokturk and Caliskan (2020) proved the effectiveness of creative drama activities implemented in an English course for 7th graders to improve learners' speaking skills. In the same context, Coyle, Holmes and King (2009) confirmed that the language focus and the content focus are interwoven. As Content and Language Integrated Learning, henceforth, (CLIL) refers to situations where subjects, or parts of

subjects, are taught through a foreign language. CLIL has changed the educational scene by adding new methods and principles in the bilingual education environment.

In a recent study for Figueroa's (2018), who investigated the impact of CLIL on speaking skills, showed the effectiveness of CLIL approach on improving students' speaking skills. Muszynska and Galazka (2017), Nunez \& Roman (2015) and Pozo (2016) in their studies affirmed that 'drama-and-CLIL' connection is powerful because of their mutual cornerstones as they mix engagement in active learning, sustainment of learner motivation, authenticity in communication, responsibility in making choices and reflecting on the process and the results. It is worth to mention that English for Palestine curriculum aims to enable Palestinian students to enhance their communicative ability of foreign language learning. CLIL focuses on the learners' use of the language in situations more than the language to be memorized. 


\section{Defining Speaking skill}

Al-zaharna (2019); Ashour (2014) and Nunan (2003) define speaking skill as a productive skill of utters, phrases and sentences by which the learner can clarify, justify, transfer his thoughts and his ideas. They see that speaking is a process in which the student can prove his/her learning language by using suitable vocabulary and structure beside his/her learning of a certain knowledge as scientific facts or scientific terms. In the same concern, (Burns \& Joyce 1997; Luoma, 2004; Eckard \& Kearny, 1981; Florez, 1999); Flors, 1999; Ulas, 2008; Howarth, 2001) defined speaking as an interactive two-way process involving a true communication of ideas, information or feelings of which it involves producing, receiving and processing information. Additionally, Torky (2006) define speaking as the learner's ability to express himself/herself orally, coherently, fluently and appropriately in a given meaningful context. In the same context, Argawati and Suryani (2017) define speaking as the practical side of language to express ideas and producing them in an expressive way effectively and communicatively.

The current study researchers state that speaking skill is a human aspect where people can express their own ideas, experiences, feelings and emotions through an interactive process with the community members. It is a mutual linguistic phenomenon with all the communities regardless their language or culture.

\section{CLIL and speaking}

CLIL is one of the modern and successful methods developed to help students reach plurilingualism. This was clear in a recent study conducted by Gonzalez-Davies (2016) which confirmed that CLIL promotes collaborative and distributed learning, and Integrated plurilingulism in teaching where the learner acquires more than one language. CLIL makes reference to teaching subjects other than the English language, such as science, geography, history, math or physical

education using the foreign language instead of the students' mother tongue. CLIL implementation is demanding for educators since the work to be done shifts from current practices to new practices favoured by this approach. As already mentioned, CLIL is a kind of bilingual education and equal emphasis is placed on both subject and language in an integrative manner, although the focus may change from time to time depending on the needs (Samper, 2015). Zafiri \& Delliou (2016) and Marsh \& Langé (2000) state that CLIL is a dual- focused approach to teaching since it aims to teaching the content and the language at the same time. The target language is used for the teaching and learning of both the content of a school subject and the language itself within a specific set of learning objectives set by the teacher. In other words, an additional language is used as a medium in the teaching and learning of a non- language content.

Pozo (2016) points out that CLIL is considered to maximize the students' exposure to the foreign language and thus create the most suitable environment for learning. In CLIL, the target language is used as a vehicle for the instruction of school subjects; it is used not only to offer knowledge, but also to convey meaning and share experience. As mentioned in Delliou \& Zafiri (2016) and Pokrivčáková \& Hanesová (2015), CLIL has become commonplace in many schools in Europe, only lately have language teachers and researchers started to experiment on the effectiveness of this method in Greece. Teaching and implementing CLIL has many implications for educators; they have to comply with the principles of the new methodology, adjust their teaching material, as well as, have a thorough knowledge of both the foreign language and the content subject. Deller and Price (2007) confirms that learners in CLIL need help in the areas of lexis, cognitive functions and study skills. This is because the students will be immersed in two situations; learn a foreign language and the content of the subject. 
Upon that, CLIL could be integrated with drama or music containing a certain culture or content and this helps developing understanding the human relationships and it is considered as a key of success to enhancing communication between humans locally or globally. Coyle, Hood, and Marsh (2010:17) confirm that a successful CLIL lesson should combine the following 4Cs which are the components of the CLIL and the basic structure:

- Content - Progression in knowledge, skills and understanding related to specific elements of a defined curriculum

- Communication - Using language to learn whilst learning to use language

- Cognition - Developing thinking skills which link concept formation (abstract and concrete), understanding and language

- Culture - Exposure to alternative perspectives and shared understandings, which deepen awareness of otherness and self.

\section{Benefits of CLIL:}

CLIL refers to "being educated in a language other than one's mother tongue" (Coyle, 2009:23). Many researchers as (Figueroa, 2018; John, 2017; Diezmas, 2016; Delliou and Zafiri, 2016; Perez \& Basse, 2015 and Cortacans, 2013) have cited benefits associated with CLIL on a language level, including an increase in students' linguistic competences, vocabulary learning skills and grammatical awareness. These researchers confirmed that CLIL has a positive effect on problem solving, risk taking and intercultural communication, and has been demonstrated to increase student motivation.

As noted in Bentley (2010:11), CLIL aims to:

- introduce new students to new concepts through studying the curriculum in a new language,

- develop leaners' production of the language of curricular subjects,

- develop students' performance in both curricular subjects and the target language,

- promote students' confidence in the target language and the mother tongue,

- provide materials which improve thinking skills from the start,

- encourage stronger connections with values of community and citizenship,

- make the curricular subject the essential focus of classroom material.

Frigols (2010) states that what working with CLIL involves:

- implementing CLIL is a natural method to language learning and build on the theoretical basis of Second Language Acquisition.

- CLIL drives the content in the language.

- CLIL improves and boosts the acquisition of cognitive skills.

- CLIL includes social learning.

- CLIL is learner-centred.

- CLIL follows a constructivist method.

All these CLIL characteristics are positive for learners and make learning a language more motivating and useful. They help the students learn a target language in meaningful way. CLIL principles are creative but not new. They can help in many aspects in English language teaching (Darn, 2006).

\section{Dramatizing the CLIL}

Pozo (2016) states that the integration of different skills using history, music and drama provides learners with a great chance to combine meaningful content within a story of ESL. He 
adds that drama in a CLIL environment helps developing understanding of human relationships. He indicates that drama and CLIL helps developing understanding of human relationships in different subjects. It also helps in ESL acquisition and makes students feel a sense of empowerment when facing acting and the teacher becomes more a facilitator than a conductor. They find it fun and easy to step on the shoes of characters of stories.

Drama and CLIL promotes a good connection as this basic philosophy is holistic and goes along with the young learners' interests and needs. This method overlaps and weaves its way through the learners' minds, souls, and bodies. Undoubtedly, drama and CLIL is a good solution for those who those who hope to move to more universal role. CLIL deals with content that is dry and technical. Drama can change this content into a dynamic one. CLIL could help in improving the cultural awareness and language competence of learners. Putting CLIL and drama can form an effective and enjoyable learning experience (Hillyard, 2015).

Nunez \& Roman (2015) state that Content and Language Integrated Learning (CLIL) has created a modern teaching method. CLIL has no fixed model and this could help the teachers to implement this method with no difficulties. Teachers can contextualize the taught items via a dramatized context and this can motivate their students.

\section{Teaching Speaking skill}

Speaking is an important skill amongst the main four skills of English. Gillis (2013), Nunan (1999), Segura (2012) and Sadiku (2015) state that to be successful in learning a language is measured according to the ability to conduct a conversation in the (target) language. Thus, speaking is probably a priority for learners of English. Speaking is basic due to its help to students to grasp EFL speaking skills. Furthermore, if the right speaking activities are taught in the classroom, speaking can raise general learners' motivation and make the English language classroom a fun and dynamic place to be. In addition, speaking can support other language skills. Oral interaction is considered as an essential factor in shaping the learner's developing language. Speaking skills can enhance one's personal life and thereby bring about the well-rounded growth that we should all seek.

\section{Teaching Speaking challenges in Palestine}

Palestinian students like other students in different contexts face difficulties in communicating orally in English. many researchers and methodologists say that in Palestine, several learners are doing better at reading, and writing, but not at speaking. Some of these challenges were stated by: Dajani \& McLaughlin, 2018) as, English language education in Palestine nowadays faces critical difficulties. Big classes, a few resources, a little access to the world wide web, and low salaries as well. In addition, a few incentives are given to teachers to be innovative in

their classes. Teacher demotivation is engaged with both a classical teaching method. The last school exam (Tawjihi) and other grades as well which have neither a listening nor a speaking exercises affects negatively learning speaking. The listening is not given at all while speaking is written as a writing exercises. This has impacted poor speaking skills in English. The Palestinians, through generations of conflict and military occupation, have always placed focus on education as a means to a better future.

Rabab'ah and Bulut (2007) asserts that teaching speaking in the Palestinian schools has been nearly neglected and English language teachers use teaching speaking just to make students memorize conversations or do some activities. They still spend the larger part of teaching time on reading and writing practices. Similarly, Elmasri, (2019), Alattar (2019), Ashour (2014), Aljadili (2014), Afana (2012), Alhabbash (2012), Obeidat (2002) and Al Wahibee (2004) in their studies confirmed that Palestinian learners face some challenges concerning pronunciation, this could be because English and Arabic are different. They assure that speaking is a difficulty for many 
students. In addition, they maintain that language anxiety performs an obstacle for learners to speak and interact in a certain speaking activity and even the lack of vocabulary hinders their speaking as well. Yet, they assured that teachers teach their students in a test-oriented method.

Based on the researchers' experience, they confirmed the above mentioned challenges to teaching speaking. Meanwhile, they believe that all these difficulties can be solved if teachers use suitable methods and techniques to teaching speaking and getting their students more engaged in the learning. In the same context, Zourob (2014) confirms that helping learners to learn English effectively needs change of the teachers' methods of teaching. Additionally, teachers should think of creative techniques that investigates the learners' interaction competencies, and give them more opportunities to speak and communicate well. Zourob also assures that promoting learners' speaking skills is one of the basic aims in English teaching in Palestine.

In Palestine, English Language curriculum includes the four skills of English language. ELC (2015) considers speaking as an important skill amongst these four skills as the ultimate goal for Palestinian learners is enable them to communicate successfully.

\section{Teaching speaking through drama}

Teaching speaking through drama has several aspects and techniques. Harmer (2007) suggests telling stories as an effective activity to enhance speaking skills for learners, he argues that spending a lot of our time telling other people stories and anecdotes about what happened to us and other people could be effective to develop speaking. He also suggests information-gaps to be one of the activities that could be used for this activity.

Ulas (2008:18) explains the benefit of learning speaking through drama as follows:

- A student grasp meaningful content better.

- Learning is shown as a result to the interaction between the student and his environment.

- The more sensory organs a student uses, the greater the retention of the lessons.

- A student learns best by doing.

- Effective participation is essential in learning emotional conduct.

- Learning becomes easier and more permanent as there is more than one stimulus.

Fabio (2015) and Goodwin (2001) confirm that drama is a particularly effective tool for teaching speaking especially pronunciation because it has different communicative competences such as: discourse intonation, pragmatic awareness and nonverbal communication. In addition, they added that drama activities foster pupils' socialization, critical thinking, problem solving and improve oral communication skills, by exploring different language styles and registers.

As teaching English language using drama methods sets a quality interactive setting in a speaking activity, and makes learners utilize the language in an interesting way. Drama could boost ahead their verbal competences as well. Trivedi, (2013) states that drama techniques enhance verbal communication, making the participants use the language both conceptually and contextually. Practically, in an empirical study of Ozturk et. al (2020) examined the impact of creative drama activities implemented in an English course for 7th graders to improve speaking skills. The results showed that the creative drama activities had a positive influence on the improvement of students in the speaking skills. Moreover, their attitudes towards the course were affected positively.

\section{The Statement of the Problem}

Researchers and experts, in the field of ELT, have tried several methods and techniques for teaching speaking. Though some of these methods are approved to be effective, there is a bad need to urge students to speak confidently and accurately. The dire need to enhance the students' English speaking skills, based on the researchers' experience as ELT specialists guided the researchers to 
speculate deeply for creative intervention. Like other EFL learners, Palestinian students can learn the skills of English speaking through engagement and interaction with the content. The related literature shows that CLIL, which is implemented mainly in Europe for teaching target languages, is an effective approach to learning a foreign language through connecting that particular language with the content that stimulates students to learn. Yet, CLIL needs some vivid elements to be added and drama can help in making CLIL more understandable. In the same regards, European commission (2019) starts a project called (Playing-CLIL) in Europe for 13 countries that aims to bring innovation and creativity to the CLIL classroom and beyond. It also aims to combine elements of drama pedagogy and drama techniques with language and content matter learning in an innovative way that emphasizes and builds the learners' speaking abilities and confidence to interact. This project confirms the effectiveness of this approach (Playing-CLIL) to enhance students' different language skills and abilities.

Thus, in this study, the researcher suggests CLIL and drama as a new integrated strategy to help learners to use the language in an interesting way.

\section{The Study Objectives}

The current research is mainly conducted to achieve the following objectives:

- To help the English teachers of $9^{\text {th }}$ graders in Palestine identify the most important speaking skills that they should work on with their students.

- To guide the English teachers use a new strategy based on CLIL and drama in teaching English speaking skills.

- To enhance the English speaking skills among the $9^{\text {th }}$ graders in Palestine in an interesting and motivating way.

\section{The Study Question}

1. What are the most important speaking skills that the $9^{\text {th }}$ graders in Palestine should possess to improve their English speaking competencies?

2. Is there any statistical significant difference at $(\alpha \leq 0.05)$ between the post-test total average score of the experimental and the control group?

\section{The Significance of the Research}

To the best of the researchers' knowledge, no previous studies were conducted based on CLIL and Drama in Palestine or within the Arab world. Thus, the results of the present study a unique contribution to the literature of teaching English speaking skills within the Arab context. Besides, the suggested method combines CLIL and drama so that learning English will be more motivating and enables students to construct their own learning through scaffolding due to the element of interest that Drama adds up.

\section{Delimitation}

the study will be implemented:

1. on speaking skills, mainly, describing sequence of events based on visual input; expressing personal feelings, emotions and the like; responding to direct questions, instructions, suggestions, offers, visual input and the like and responding to referential, inferential and factual questions.

2. in the scholastic year 2019-2020.

3. on $9^{\text {th }}$ graders.

4. in Gaza Governorate

\section{Definition the Study Terms}


- Speaking skills: it is the way of conveying information and expressing one's feelings and thoughts in a spoken language act.

- CLIL: CLIL stands for Content and Language Integrated Learning and refers to teaching subjects such as science, history and geography to students through a foreign language.

- Drama: it's a story or a play that conveys a meaningful idea to readers. It could fiction or nonfiction; artificial or authentic.

- CLIL and Drama: it's a new strategy that dramatizes CLIL and makes it more motivating to learners of foreign languages.

- 9 ${ }^{\text {th }}$ Graders: students who are nearly 15 years old and are in grade 9.

\author{
Abbreviations: \\ CLIL Content and Language Integrated Learning \\ UNRWA United Nations Relief and Works Agency for Palestine Refugees in the Near East. \\ ELC English Language Curriculum \\ EFL English as a foreign language
}

\title{
Literature Review
}

To the best of the researchers' knowledge, only two related studies investigated the CLIL and drama on learning. Several studies investigated CLIL and its impact on speaking or drama and its impact on speaking. In this section, the researchers divide the studies into three sections: first; CLIL and drama impact on learning a language; second, CLIL and its impact on developing speaking skills; third, drama and its impact on speaking skills.

\section{First: the impact CLIL and drama on learning a language}

1. Muszynska and Galazka's (2017) study explored the new teaching methodologies in the teacher education regarding CLIL and drama. The study depended on data from the basis of other European countries' experience, including the United Kingdom and Poland. The material was an academic course on drama designed for students who were studying a degree in Early Childhood, Primary Education. The tools of the study were a questionnaire and personal interviews. Results showed that many effective characteristics of the CLIL and drama were observed. In addition, the practice-focused phase proved that drama improves various skills and attitudes pursued in CLIL approach. The results also provided guidelines for teachers of how to fulfil drama-based-process- and product-centered educational objectives. In the same concern, the findings showed that teaching through drama and CLIL can develop students' critical and creative thinking and enhance their participation in a shared learning experience.

2. Pozo's (2016) study investigated whether studying historical content via a new approach where we can get better results than traditional methods of learning history. The researcher tried to show differences in learning the Industrial Revolution using a traditional methodology which relies on the textbook in contrast with a Content and Language Integrated Learning (CLIL) approach which included drama and music. The study was implemented at a public Secondary School in a town in Eastern Madrid. 682 students were enrolled at the school and the staff was 81 teachers. The study results confirmed that teaching history for some topics where drama and music are used is more effective than a textbook-based teaching.

\section{Second: the impact of CLIL on developing speaking skills}

1. Figueroa's (2018) study investigated the analysis of the impact of 3 CLIL workshops on 2 speaking micro skills which are language chunks and lexical units. This study was implemented in a public higher education college in Bogotá. The sample was 20 students undertaking information technology degrees. The 3 workshops were made up of 5 lessons each that gave speaking skills priority; yet, they focused on all the language skills throughout the lessons. The study followed the 
qualitative research approach. The tools were field notes, audio recordings, interview, in addition to students' artifacts. The information was analyzed in terms of the grounded theory approach and the color coding technique. The results showed that the workshops' design and implementation of communicative tasks influenced, positively. Additionally, the use of the 2 speaking micro skills was influenced positively as well.

2. John's (2017) study used scaffolding to develop the learner's oral fluency and speaking skills outside and inside the classroom in order to speak effectively in academic and non-academic situations. The study combines CLIL and CLT (communicative language teaching) to develop the speaking skills of students. The study investigated how engineering college learners of English responded to scaffolding through their interactive sessions. Teacher-led interactions were implemented and the progress of the learners of the language was analyzed periodically. This study took place in Tamil Nadu College in India. The

participants were one class of fifty-seven, who were enrolled in the tertiary-level of first year majoring in engineering. The study used classroom lectures, interactions of small groups, and discussions which are teacher-led in 2 settings: The Regular English Class and the other is the Daily Tutorial Class. The results indicate that the learners responded adequately through the interactions and were influenced in a positive way. What was most significant is that the students realized that they were able to interact in English. The findings showed that the students could use the interactions they have learnt in the real life situations. Thus, they started rehearsing several polite expressions.

3. Delliou and Zafiri's (2016) study examined the potential of CLIL to develop the speaking skills of learners in grade 6. It is mainly based upon the hypothesis that considers the CLIL approach as an aid for students to develop their speaking skills to be more effective than the traditional methodology. The setting of the study was the Greek State Primary Schools which is located in a rural area in Greece. the sample was 30 students belonging to 2 different state primary schools in the area. They were divided into 2 groups of 15 students each. They aged 11 years old. They were in grade 6 . The data were analyzed using the quantitative and qualitative methods. The tools were a speaking test of the national certificate of competence of foreign languages. Another tool was a classroom observation checklist of the CLIL lessons. In addition, a questionnaire was used to investigate the learners' attitude towards the CLIL approach. The results showed the effectiveness of CLIL to develop the speaking skills of students. Moreover, their attitude was positive towards the new teaching approach of CLIL.

4. Diezmas's (2016) study investigated the impact of Content and Language Integrated Learning (CLIL) in the acquisition of the competences of English language including speaking and interaction in comparison with the traditional methodology of learning English as a foreign language (EFL). The participants were 4th graders in primary schools aged between 9 and 10 years. The sample of the study was the census of all schools in Castilla-La Mancha in Spain. The results showed that the only communicative competence was spoken production and interaction favouring CLIL students.

\section{Third: the impact of drama on developing speaking skills}

1. Ozturk et. al's (2020) study examined the impact of creative drama activities implemented in an English course for 7th graders to improve speaking skills. In order to collect the data for the study, the researcher implemented a speaking exam, speaking rubric, an attitude scale in addition to lesson diary. The study used two units in the teaching program of Primary School English Language in Turkey. Lesson plans involving creative drama tasks were designed so as to help learners gain the speaking skills of the assigned units. The sample of the study was 21 students (12 boys, 9 girls). The study lasted for 10 weeks. The tools of the study 
were; an attitude scale and a speaking exam for students. Whereas, creative drama activities were implemented for 8 weeks. The data were analyzed quantitatively through paired sample t-test. In addition, an inductive approach was adopted to analyse the qualitative data. The results showed that the creative drama activities had a positive influence on the improvement of students in the speaking skills. Moreover, their attitudes towards the course were affected positively.

2. Muthohar et. al's (2019) study explored the use of drama to build up autonomous English learning toward the learners of International class program of IAIN Salatiga batch 2018. The participants were 20. The students' oral production was analyzed in the process of implementing drama speaking class concerning verbal components of drama which were pronunciation, fluency, articulation and accuracy (grammar \& vocabulary). The tools of the study were scoring sheet for learners' speaking performance, recording and transcription. Fourteen meetings were conducted to implement the drama performance. As a result, two conclusions were confirmed: the first, it can be said that the use of drama performance is effective to improve autonomous learning habit of learners. They were able to improve their potential in maximum way and learn together in their peer learning group. The second conclusion was, from the given questionnaire's responses, dealing with the strength of the use of drama to improve learners' autonomous learning, it can be said that there were 16 students who felt that drama performance can develop their speaking ability, mastery of vocabulary and raise their self-confidence. In the same context, 17 students responded saying that there was no weakness in the use of drama to build autonomous learning.

3. Mahrous's (2019) study investigated the effectiveness of using a drama techniques-based program to develop EFL speaking skills and to reduce speaking anxiety among secondary stage learners. The participants of the current study were 40 in the first year of the secondary level students in Mohamed Mekawy Secondary School in Aswan, Egypt. The study used the one group pre-posttest quasi-experimental design. The participants were trained to use specific drama techniques when responding to speaking tasks and activities. The tools of the study were a speaking test and a speaking anxiety scale. The findings revealed that the drama techniques-based program was effective to develop EFL speaking skills and to reduce speaking anxiety among first year of secondary level students.

4. Alsharif's (2019) study aimed to specify the required speaking skills for the learners of the first level intermediate stage in Makkah Almukaramah and to explore the effectiveness of using the educational drama strategy to develop their speaking skills of the following: to pronounce the words in a correct way using meaningful sentences, to control the intonation and tone due to the situation and to have a rich linguistic inventory. The researcher followed the quasi-experimental design. Two groups of 120 students were the sample of the study, (60) in the experimental group and the same in the control one. An observation sheet had been implemented (pre-application) to measure the oral performance (speaking skills) of both groups. The results of the study showed that there were statistical differences between the mean scores of both groups in the (post-app.) favoring the experimental group. This was clear in the observation sheet to measure the oral performance (speaking skills).

\section{CONCLUDING REMARKS}

After reviewing the previous studies, the researchers found that only a few studies investigated CLIL and drama effect on learning as (Pozo, 2016 and Muszynska \& Galazka, 2017). The studies were conducted in Europe and the results showed positive effect of teaching CLIL via drama. In the same concern, several studies examined the effect of CLIL on developing speaking skills or communication skills as (Figueroa, 2018; John, 2017; Delliou \& Zafiri, 2016 and Diezmas, 2016). The studies were conducted mainly in Turkey and Spain. The results showed that CLIL is a good strategy to enhance students' communication skills and even to change their attitudes towards learning English. Additionally, there were recent studies as (Ozturk et. al, 2020; Muthohar et. al, 
2019; Mahrous, 2019 and Alsharif, 2019) in different countries and investigated drama and its effect on improving speaking skills of EFL learners. The results of these studies assured that drama is an interesting technique that could be used inside classrooms to enhance students' speaking skills.

The previous studies enriched the researchers' bank of knowledge to design and choose the suitable instruments of collecting the data. In addition, they got enriched from the literature review and the outline of the study. On the other hand, the researchers found no certain study that investigates CLIL and drama to improving students' speaking skills. Thus, this study is a unique study to examine such a topic that adds a new interesting approach of teaching to the methods of teaching English.

\section{Design of the Study}

The study followed the quasi-experimental approach where two groups were assigned as the participants of the study; the experimental group, and the control group. The research includes two variables; the independent variable is CLIL and drama. The dependent variable is speaking skills.

The experimental group was taught the dramatized passages, while the control group was taught the syllabus-based passages.

(40) lessons (of 45 minutes for each) were given to students within (4) weeks started from 1st Feb., 2020 and ended on 1st March, 2020. The (40) lessons were divided into (10) reading lessons and (30) speaking ones. Two reading texts (unit 9 and 10, second term) from the English textbook for grade nine were dramatized. The content is appropriate for the learners' level. Additionally, the researcher took into consideration the opinions of the referees as specialists in drama scenario writing, professors of teaching methodology, supervisors of English language in addition to qualified and experienced English. When designing the program, the researcher took into account the level of the students in order to meet the inclusive practices inside classroom. The researcher implemented a similar dramatized reading text on a pilot study which consists of (20) students from Al-Mamonia Preparatory Girls' school. This step was to investigate if there were unclear instructions and activities or ambiguity of the texts.

\section{The Sample of the Research}

The sample of the study consisted of (68) students distributed into two groups; one experimental group consists of (34) students and one control group includes (34) students. The groups were chosen randomly from East Gaza Education Area in the Gaza Strip. The sample was from Al-Mamounia Preparatory girls' school A for Palestinian Refugees. Randomly, two classes were selected. One of the researchers of the study, (Aladini, A.), taught both groups of the students The students in both groups were equivalent economically, culturally, socially and in their general achievement. The students aged 15 years.

\section{THE TOOLS OF DATA COLLECTION}

The researchers prepared a checklist of the speaking skills from the ELC 2015. These speaking skills were (17) and teachers had to decide the most important ones. Based on the results, the test was designed accordingly.

\section{A checklist of speaking skills:}

English Language Curriculum (2015) document has prepared general aims of speaking skills for students of grade nine. The researchers used these aims as a checklist. The items of the checklist are 17 speaking skills. This checklist aimed to measure the importance degree of the skills of speaking that should be developed in the program based on CLIL and drama and to be used to build the pre-post test. Teachers and supervisors were asked to rate the items as follows: $(3)=$ very important, (2) = important, $(1)=$ slightly important. 


\section{Validity of the checklist}

The researchers used the speaking skills that should be used in the English for Palestine curriculum - grade nine to improve students' communication competency. These speaking skills were decided by the curriculum designers in the Ministry of Education. These designers were university professors, educational supervisors and all this was supervised by the British Macmillan publishing Institute.

\section{The application of the checklist}

The checklist was applied on (11) English Language supervisors and (12) teachers to rate the speaking skills. Based on the results, four skills (chart 1) out of (17) (Appendix 2) got more than $(90 \%)$.

\begin{tabular}{|l|c|c|}
\hline No. & Skills & $\begin{array}{c}\text { Relative weight } \\
\mathbf{\%}\end{array}$ \\
\hline $\mathbf{1}$ & Describe a sequence of events based on visual input. & $\mathbf{9 5}$ \\
\hline $\mathbf{2}$ & Express personal feelings, emotions and the like & $\mathbf{9 0}$ \\
\hline $\mathbf{3}$ & $\begin{array}{c}\text { Respond to direct questions, instructions, suggestions, } \\
\text { offers, visual input and the like }\end{array}$ & $\mathbf{9 5}$ \\
\hline $\mathbf{4}$ & Respond to factual, referential and inferential questions. & $\mathbf{9 5}$ \\
\hline
\end{tabular}

\section{Achievement test}

A pre-post achievement test was conducted by the researchers to measure the students' achievement in speaking skills. (Appendix 1)

\section{The general aims of the test:}

The test aimed at measuring the effect of a suggested program based on CLIL and drama improving on the students' speaking skills. It was built according to the criteria of the test specification. The objectives of the test were to examine the students' ability to:

- Describe a sequence of events based on visual input.

- Express personal feelings, emotions and the like.

- Respond to direct questions, instructions, suggestions, offers, visual input and the like.

- Respond to factual, referential and inferential questions.

The test items are 4 items. The items are equal in weight. Students were tested before and after the intervention process. The researchers used a rubric speaking criteria for oral testing. It contains fluency, coherence, vocabulary, structure and pronunciation. This criterion was use to authentically assess speaking using the real assessment tool. (see Appendix 2)

\section{The Source of Constructing the Test:}

The researchers depended on English for Palestine - grade nine syllabi which was applied from 2000 to 2015 taking into consideration the change that happened to the curriculum after 2015 .

\section{The items of the test:}

Four questions were included in the test. They mainly test speaking. They were similar to the speaking activities in the textbook for grade nine and suit all levels of students; the items were as follows:

Question 1 in this question, students are to look at four sequenced pictures and describe them. The rubric is: Look at the following pictures then write sentences to form a meaningful story: 
The objective is: Describe a sequence of events based on visual input.

Question 2 it consists of five Wh-questions which ask about personal feelings and opinions.

The rubric is: Answer the following questions:

The objective is: to express personal feelings, emotions and the like.

Question 3 it consists five pieces of discourse where students should complete the missing part to respond to suggestions, offers or direct questions and the like.

The rubric is: complete the following:

The objective is: to respond to direct questions, instructions, suggestions, offers, visual input, and the like.

Question 4 it consists of five questions containing referential, inferential and factual questions.

The rubric is: answer the following questions:

The objective is: Respond to factual, referential and inferential questions

The validity of the test:

(20) Students sat for the test to examine its reliability and validity of the test.

The test was presented to education specialists, teachers of English from UNRWA and public schools. They suggested that the test should be given orally and an assessment tool should be used. The test was modified.

Pearson Formula was used to check the internal consistency validity of the test (table1).

Table (2)

\begin{tabular}{|c|l|c|c||}
\hline No. & & Pearson Correlation & Sig. value \\
\hline 1 & Q1 & $0.762 * *$ & 0.001 \\
\hline 2 & Q2 & $0.458 *$ & 0.042 \\
\hline 3 & Q3 & $0.643 * *$ & 0.002 \\
\hline 4 & Q4 & $0.586 * *$ & 0.007 \\
\hline
\end{tabular}

Correlation coefficient is statistically significant at the level 0.01

Correlation coefficient is statistically significant at the level 0.05

It is clear that all test domains are correlated statistically. The results were between 0.458 and 0.762 where the first question (domain) got the highest degree and the second got the lowest degree. The results confirmed that the test is valid.

The test reliability:

The results were (0.70) and this shows the reliability of the test.

Table (3)

\begin{tabular}{|c|c|}
\hline ITEM & VALUE \\
\hline Part one covariance & 0.829 \\
\hline Part two covariance & 0766 \\
\hline Correlation a two parts & 0.54 \\
\hline Spearman brown & 0.70 \\
\hline Gutman split-half & 0.70 \\
\hline
\end{tabular}

From Table (3), the test is reliable.

\section{The suggested program}

\section{The objectives}

It aims to improve $9^{\text {th }}$ graders' speaking skills. 
- Describe a sequence of events based on visual input.

- Express personal feelings, emotions, etc.

- Respond to direct questions, instructions, suggestions, offers, visual input, etc

- Respond to factual, referential and inferential questions.

\section{The design}

The researchers reviewed the literature of how to connect between CLIL and drama and then designed the program accordingly. They designed two drama-based-reading texts included in the grade nine textbook. (see Appendix 3)

\section{The content}

Two reading texts (unit 9 and 10, second term) from English textbook for grade nine were dramatized. Additionally, the researchers took into consideration the opinions of the referees as specialists in drama scenario writing, professors of teaching methodology, supervisors of English language in addition to qualified and experienced English. When designing the program, the researchers took into account the level of the students in order to meet the inclusive practices inside classroom.

\section{Implementation:}

The researchers implemented one scenario on (20) students to check ambiguity.

Two reading lessons of (45) minutes are taught every week. After that, students were to study two speaking lessons, 45 minutes for each, depending on the reading passages they have learnt recently. The program started on $1^{\text {st }}$ Feb., 2020 and ended on $1^{\text {st }}$ March, 2020.

\section{Assessment}

The researchers used formative assessment included in the program to scaffold students' learning. Students were assessed continuously using different assessment techniques and activities.

\section{Results of the Study}

Question (1) What are the most important speaking skills that the students should possess to improve their English speaking competencies?

English Language Curriculum (2015) document designed new syllabi almost for all grades including grade nine. This new syllabus shows aims and objectives for each school level and each language skill. As stated, the aim of the language is oral and written which is primarily a means of communication in multiple and several social situations to express themselves, interact with others, learn international issues, and meet their individual and different needs. Successful language learning and language teaching emphasize the goal of functional proficiency.

The skills that $9^{\text {th }}$ graders should possess are as follows:

1. Articulate sounds in isolated form and connected speech.

2. Articulate stress patterns within words.

3. Produce basic intonation pattern.

4. Manipulate variation in stress in connected speech.

5. Summarize the main points of a text.

6. Describe a sequence of events based on visual input.

7. Narrate a story based on personal experience.

8. Narrate a story based on a strip-story.

9. Make a rehearsed or unrehearsed presentation about a familiar topic.

10. Express personal feelings, emotions, and the like ...

11. Respond to direct questions, instructions, suggestions, offers, visual input, and the like ... 567 
12. Respond to factual, referential and inferential questions.

13. Respond to conditional or hypothetical questions.

14. Give directions and instructions.

15. Ask about routine matters.

16. Talk about inferred attitudes, feelings based on aural text or visual stimulus.

17. Make predictions about a piece of discourse.

The researchers used a checklist of the preceded 17 skills as a tool for teachers and supervisors to decide the ones that are most important for $9^{\text {th }}$ graders. Thus, the skills that got more than $90 \%$ were the most important skills, these skills were as follows:

1. Describe a sequence of events based on visual input.

2. Respond to direct questions, instructions, suggestions, offers, visual input, and the like

3. Respond to factual, referential and inferential questions.

4. Express personal feelings, emotions, and the like

The teachers and the supervisors considered describing pictures or visual inputs as one of the most important skills. This is confirmed by the previous studies that learners of a language should talk about events or visual inputs as this assures their ability to use this language effectively. In addition, responding to direct questions, instructions, suggestions, offers, factual, referential, inferential questions or expressing feelings and emotions were important as well.

\section{Question (2) To answer the second question of the study which is stated as: Is there statistical significant difference at $(\alpha \leq 0.05)$ between the post-test total average score of the experimental group and the control group?}

To answer this question, a pre-posttest of speaking skills was administrated. The mean scores and standard deviations of the students' scores on the speaking pre-test and post-test were calculated, along with estimates mean scores and standard deviations of the post-test scores as shown in table (4):

Table (4) T-Test, means and standard deviation of students' speaking skills oral test in the post-test.

\begin{tabular}{|c|c|c|c|c|c|c|c||}
\hline Test & Group & N & Mean & Std. Deviation & T & Sig. value & sig. level \\
\hline \hline \multirow{2}{*}{ Speaking skills } & experimental & 34 & 15.4 & 1.6 & \multirow{2}{*}{7.53} & \multirow{2}{*}{0.001} & \multirow{2}{*}{ sig } \\
\cline { 2 - 8 } & control & 34 & 11.7 & 2.3 & & & \\
\hline
\end{tabular}

Depending on the analysis of the results of the achievement test. The table shows the mean of the experimental group which is 15.4 and the control group is 11.7 and this shows that the experimental group students got higher marks than the control one. In addition, calculated T. is 7.53 and the significance value is 0.001 . Thus, these results confirm that the suggested program based on CLIL and drama is effective and gave positive results.

Size effect was calculated from the collected data by the researchers using the size effect rule of T-test for two independent samples as clarified by Afana (2016:217):

$$
\eta^{2}=\frac{t^{2}}{t^{2}+d f}
$$

Accordingly, the size effect is $\eta^{2}=0.46$ and this indicates a very big size effect based on the effect size levels clarified by Afana (2016:52) and the results were as follows: 


\section{Discussion and conclusion}

\begin{tabular}{c|l|l|l|l|}
\multicolumn{1}{c}{$\begin{array}{c}\text { The } \\
\text { study }\end{array}$} & The scale & Big & Medium & small \\
\cline { 2 - 5 } & $\eta^{2}$ & 0.14 & 0.06 & 0.01 \\
\hline
\end{tabular}

current aims at

investigating the effect of a suggested program based on CLIL and drama to develop students' speaking skills.

The first question which is stated as follows: What are the most important speaking skills that the students should possess to improve their English speaking competencies?

The researchers used a checklist of the speaking skills included in the English Language Curriculum document and presented these skills which were (17) to the teachers and the supervisors to decide the ones that are most important for $9^{\text {th }}$ graders. Thus, the skills that got more than $90 \%$ were the most important skills, these skills were as follows:

1. Describe a sequence of events based on visual input.

2. Respond to direct questions, instructions, suggestions, offers, visual input, and the like

3. Respond to factual, referential and inferential questions.

4. Express personal feelings, emotions, and the like

From the result of the first question, we can conclude that teachers and supervisors in Palestine believe that students can be fluent if they can describe pictures and respond to different types of questions.

The second question of the study examines whether there are statistically significant differences among ninth grade students' speaking skills. This is attributed to the new used strategy (CLIL and drama). The statistical analysis of the data indicated that there was a significant difference on the achievement of the students' speaking skills at the level of $(\alpha=0.05)$ favouring the experimental group. Apparently, the study results show higher marks of the experimental group than their peers at the control group in the speaking skills which are (describe a sequence of events based on visual input; express personal feelings, emotions, and the like; respond to direct questions, instructions, suggestions, offers, visual input, and the like; and respond to factual, referential and inferential questions. The mean score of the experimental group was 15.4 out of 20 which indicates much progress in the achievement of the students during the intervention. It is worth to say that the teacher who used the suggested program based on CLIL and drama used the scale of the rubrics of the speaking skills (fluency and coherence; vocabulary; structure and pronunciation).

As shown in the results, the program CLIL and drama showed improvement in the students' speaking skills achievement. Pozo (2016) confirmed in his study that teaching history through drama is more effective than a textbook-based teaching. In Muszynska and Galazka (2017) study, they maintained that drama improves various skills who study a certain topic via CLIL approach. The results also provided the teachers with outlines of how to use drama-based-process- and product-centered educational objectives. In the same concern, the findings showed that teaching through drama and CLIL can develop students' critical and creative thinking and enhance their participation in a shared learning experience.

Moreover, Hillyard (2010) and Hillyard (2015) developed a link to connect between Drama characteristics and five CLIL components. This connection was beneficial for several learning purposes. Lantix, Learntix, Contix, learning outcomes and engagement were used as the connecting components of CLIL. This connection between Drama and CLIL includes aspects which are interesting and motivating forces to be used in the class. In addition, they are holistic and fully engages the learner. CLIL and drama can be characterized as a context and problem focused method. Also, it can develop analytical thinking skills and stimulate creativity and arouse the 
learners' motivation through promoting his autonomy. In the same context, this approach can develop the linguistic functions and the cross curricular aspects. Hillyard concludes that mixing drama and CLIL is a promising solution for the difficulties that are faced in the language classroom.

Drama and CLIL could be an effective method due to the current study findings for English language learning in Palestine as they have some challenges. There are large number of students in classes and many demotivated teachers who have few incentives. Singh et al., (2018) states that in crowded classes, students are not able to receive suitable attention or opportunity to participate. Afana (2012) and Elmasri (2019) confirm that teachers don't pay much attention to speaking skills as the speaking activities are taught through reading or writing skills and are assessed in written form through written conversations, dialogues and even written description for a visual input. Young Palestinians need to learn English in a modern way that enables them to pronounce English vocabulary and use structures correctly. They don't have to be very fluent but to be able to speak in a range level that makes communication understandable. English has been a core subject in the Palestinian National Curriculum. It's compulsory taught in the first grade (students of 6 years) to grade 12 (students of almost 17 years).

In the suggested program based on CLIL and drama, there are some activities that give students a chance to express their own story or create their own drama. Thornburry (2013) and maintains that drama in the English language classroom ticks all the right boxes, particularly if it's re-told, created and performed by learners. Students of Gaza and the West Bank (Palestine) show enthusiasm when they compose and then perform a story or listen to it. It could be said that, drama is participatory as it includes a group of learners who learn, compose and perform a play. Additionally, it is interactive as drama includes a communicative to-and-fro which replicates reallife interaction. Moreover, this performance is oral. It activates the learners' speaking skills. Their level of pronunciation, and both accuracy and fluency are to be promoted and improved accordingly. It's important to say that drama is expressive. Clearly, it gets students think of an imagined world with the thoughts, experiences, feelings, fears and hopes.

Thornbury adds that "in the context of Palestine drama provides a means of thinking the unthinkable, of saying the unsayable, of dreaming the undreamable. And it is transformative: it empowers its creators by enhancing their English skills, and hence giving them a powerful voice in the wider world, by construing their lives as narratives that can be performed and shared, drama eloquently affirms their identity as Palestinians and as global citizens" (2018:18). In the same context, Nick Bilbrough, the founder of Hands Up Project which is mainly concerned with play writing, confirms that creating plays provides Palestinian children with a platform in which they can express and explore the issues that are important in their lives. He adds that people express themselves and their ideas not only through the words that we use, but also, through facial expressions, with gestures and with physical movements (Bilbrough, 2020).

The suggested program based on CLIL and drama gives students the ability to learn English, get knowledge, improve the thinking skills and develop the teamwork competency. Obviously in this program, the activities include (work in pairs or groups) and this could get students more indulged in the collaborative work with their peers. The learners of the experimental group in this study responded enthusiastically to the synergy between CLIL and embodied drama pedagogy. They showed high levels of engagement with their teacher. Additionally, they were engaged with the subject and with the dramatized texts. Their comments were an indicator of their motivation to continue learning English through the same method. 


\section{Conclusion:}

The results show that students who learnt English through CLIL and drama have significantly improved their level of English speaking skills and language elements. Even though the allocated time for the intervention wasn't that enough to get better results even to improve other skills as well. The current research is unique in its idea as it dealt with combining both CLIL and drama on developing an essential language skill, speaking. There are many studies related to CLIL and its effect on speaking or drama and its effectiveness on speaking skills. But the researcher didn't find any previous studies that handled both CLIL and drama together and their effect on speaking skills. Yet, Pozo, E. (2016) handled the CLIL and drama to investigate its effectiveness on enhancing the historical content. The results of this study showed that the use of drama and music is effective on teaching history. Thus, the researchers try this new method to dramatize the CLIL to enhance students' speaking skills and this is new in Palestine. This makes the topic important to the Palestinian students. CLIL and drama is noted to be motivating and match the students' proficiency levels in a foreign language. In addition, CLIL students have to be active learners through engaging them in authentic, meaningful, and interactive tasks and activities. Any disregard for one of these factors would impede the success of the CLIL implementation.

Thus, Drama and CLIL is a suitable environment for the English Curriculum for the Palestinian learners. Dramatizing the CLIL makes understanding the content easier as it is greatly connected to learners' life though an interesting method that helps them interact with different situations better.

\section{Recommendations:}

In the light of the study results, the researchers recommend that:

- curriculum designers and stakeholders in Palestine should dramatize the topics in the English curriculum in an interesting and motivating way,

- teachers should use active learning strategies that are based on drama with their students as they enhance their speaking skills,

- $\quad$ teachers should use speaking skills rubric criteria to assess students' speaking skills,

- $\quad$ and researchers should investigate CLIL and drama on developing other English skills.

\section{References:}

Afana, E. (2016). Effect size scales and referential statistics in the educational and psychological studies. Mansour publishing and print. Gaza. Palestine.

Al-sharif, F. (2019). The effectiveness of educational drama on developing first graders' speaking skills in English language. Um El-qurra journal, 11 (1).

Alattar, R. (2019). The Effectiveness of Using Scenario-Based Learning Strategy in Developing EFL Eleventh Graders' Speaking and Prospective Thinking Skills. Unpublished MA thesis. IUG.

Aljadili, M. (2014). The effectiveness of using virtual classes on developing the tenth graders' speaking skills and their speaking anxiety. Unpublished MA thesis. IUG.

Alwahibee, M. (2004). "Revival of Role-play: The Effectiveness of Role-play Activities in Learning English as a Foreign Language by Saudi College Students". J. King Saud Univ. Lang. \& Translation, 16 (1), 25- 48

Al-zaharna, Kh. (2019). The Impact of Using SIOP Model Based on Active Learning on Developing English Language Speaking Skills Among Six Graders. Unpublished M.Ed thesis. IUGaza. 
Argawati, N., \& Suryani, L. (2017). Teaching writing using think-pair-share viewed from students' level of risk taking. English Review: Journal of English Education, 6(1), 109-116.

Ashour, J. M. (2014). The Effect of Using a Videoconferencing-based Strategy on UNRWA 9th Graders' English Speaking Skills and their Attitudes towards Speaking. The Islamic University of Gaza, Gaza, Palestine, Unpublished Master Thesis

Bilbrough, N. (2020). Making a drama out of a crisis. Linking, Developing and Supporting Early Years, Primary and Secondary ELT Professionals Worldwide. YLT. IATEFL. Retrieved on: $27^{\text {th }}$ May, 2020. From: https://yltsig.iatefl.org/2019/03/01/making-a-drama-out-of-a-crisis/

Burns, A \& Joyce, H. (1997). Focus on Speaking. Sydney: National center for English Language Teaching and Research.

Cortacans, E. (2013). Speaking in the CLIL classroom: to what extent do teachers and students use English in the classroom?. Facultat d'Educacio' traduccio' I Cie'ncies humanes. Universitat de Vic. 23-33.

Coyle, D., Hood, P., and Marsh, D. (2010). CLIL. Content and Language Integrated Learning. Cambridge: Cambridge University Press.

Coyle, D., Holmes, B. \& King, L., 2009. Towards an intergrated curriculum: CLIL National Statement and Guidelines. London, United Kingdom: Languages Company.

Dajani, D. \& Mclaughlin, S. (2009). Implementing The First Palestinian English Language Curriculum: A Need for Teacher Empowerment. Mediterranean Journal of Educational Studies, 14 (2) 27-47.

Diezmas, E. (2016). The impact of CLIL on the acquisition of L2 competences and skills in primary education. International journal of English studies. University of Murcia.

Delliou, A. and Zafiri, M. (2016). Developing the speaking skills of students through CLIL. A case of sixth grade Primary School students in Greece. The $5^{\text {th }}$ Electronic International interdisciplinary conference. August 8- 12. 2016. Available online: www.eiic.cz.

Eckard, R. \& Kearny, M. (1981). Teaching Conversational Skills in ESL. Washington: Center of Applied Linguistics. Available online: www.centrewashingtonappliedlinguistics.com

Elmasri R. (2019). The Role of Work-Based Learning Approach in Enhancing Employment for Technical and Vocational Education and Training Graduates From the perception of the TVET providers and Employers in the Gaza Strip. Unpublished MA thesis. IUG

European commission (2019). Content and language integrated learning inspired by drama pedagogy. Playing CLIL. A project 2014-2019 in Europe. Retrieved on: 10 ${ }^{\text {th }}$ june, 2020. Available online: http://www.playingclil.eu/type/video/

Fabio, T. (2015). Drama techniques to enhance speaking skills and motivation in the EFL secondary classroom. Published Master thesis. Matritensis Universitas

Figueroa, L. (2018). ICT Workhops Based on CLIL to Impact Speaking. Published Master thesis. Universidad Externado de Colombia.

Florez, M. A. (1999). "Improving Adult English Language Learners' Speaking Skills". ERIC Digest. (ERIC Document Reproduction Service No. ED: 435204 )

Flors, M. (1999). Improving adult English language learners speaking skills, ERIC Daumemt Reproducation Service on ED 435204.

Gillis, G. (2013) The importance of speaking skills. Gerald Gillis website. Retrieved on: $27^{\text {th }}$ May, 2020. From: http://www.geraldgillis.com/importance-speaking-skills/ 
GONZALEZ-DAVIES, M. (2016) CHILDREN'S LITERATURE AND PLURILINGUALISM IN A TEACHER TRAINING PROGRAMME. A CLIL APPROACH FOCUSING ON DIDACTICS (FOD). EDETANIA 49, 91-105.

Goodwin, J., (2001). Teaching pronunciation. In M. Celce-Murcia, Teaching English as a second or Foreign Language, 3 (1) 26-45.

Harmer, J. (2007). How to Teach English. UK, Longman.

Hillyard, S. (2015) - Drama and CLIL: The Power of Connection. Online course. Ministry of Education. Argentina. Available online: http://biblioteca.unisabana.edu.co/publicaciones/index.php/laclil/index

Hillyard, S. (2010). Drama and CLIL: The power of connection. Humanising Language Teaching, 12(6). $\quad$ Retrieved on $22^{\text {nd }}$ May, 2020: from https://www.academia.edu/915050/Drama_and_CLIL_The_Power_of_Connection

Howarth, P. (2001). Process Speaking. Preparing to Repeat Yourself. MET. 10 (1) 39- 45

John, D. (2017). Integrating CLIL with CLT to Develop Speaking Skills in the Engineering Classroom. Researchgate online journal. St. Joseph's College of Engineering, Chennai, India. Available online: www.Researchgate.com

Keshta, A. (2001). Alternative Approaches for Teaching English Literature to Undergraduate Students in Gaza Strip . Unpublished Ph.D. University of Houston, USA .

Luoma, S. (2004). Assessing Speaking. Cambridge: Cambridge University Press.

Mahrous, A. (2019). Using Drama Techniques For Developing EFL Speaking Skills And Reducing Speaking Anxiety Among Secondary Stage Students. Faculty of Education journal, Asyout University, Egypt. https://search.mandumah.com/Record/1025527

Marsh, D. and Langé, G. (eds.). (2000). Using languages to learn and learning to use languages. Finland: University of Jyväskylä.

Miller, L. (2001). A Speaking Lesson. How to Make the Course Book More Interesting? MET. 10 (2) $25-29$.

Muthohar, A; Rini, S.; Famularsih, S. \& Risdianto, F. (2019). The use of drama to develop English speaking autonomous learning. Seword Fressh Indonesia, EAI. 22 (1).

Nunan,David. (2003). Practical English Language Teaching. New York: McGraw-Hill Company inc.

Muszynska, A. and Galazka, A. (2017). Teacher Education through Drama. CLIL Practice in the Spanish Context. Estudios Sobre Educación 32 (1) 179-195

Nunan, D. (1999). Second Language Teaching and Learning. Boston: Heinle \& Heinle Publishers.

Nunez, J. and Roman, S. (2015). Drama and CLIL: a new challenge for the teaching approaches in bilingual education. Linguistic insights 194 (1).

Obeidat. R. (2002) Content and Representation of Women in The Arab Media. United Nations Division for the Advancement of Women (DAW). EGM/MEDIA/2002/EP.11. Lebanon. Available online: https://www.un.org/womenwatch/daw/egm/media2002/documents.html.

Ozturk, M.; Gokturk, O. \& Caliskan, M. (2020). The Effects Of Creative Drama Activities On Developing English Speaking Skills. Journal of Inquiry Based Activities (JIBA) 10 (1) 1-17

Palestinian National Authority (1999). English Language Curriculum (ELC) for Public Schools Grades 1-12. Macmillan Publishers. 
Perez, M. and Basse, R. (2015). Analysing errors of CLIL and non-CLIL primary school students in their written and oral productions: a comparative study. Science direct. Procedia-social and behavioural sciences 173 (1) 11-17.

Pokrivčáková, S. and Hanesová, H. (2015). CLIL in Foreign Language Education: e-textbook for foreign language teachers. Nitra: Constantine the Philosopher University. 282 (1)

Pozo, E. (2016) Learning History and English through Drama and the CLIL Approach. Plus journal. IES Manuel de Falla (Madrid).

Rabab'ah, G., \& Bulut, D. (2007). Compensatory strategies in Arabic as a second language. Poznań Studies in Contemporary Linguistics, 43(2), 83-106.

Rao, P. (2019). The role of English as a global language. Research Journal Of English (RJOE) 4 (1) $35-50$.

Rathore, Ch. (2016) Drama-based, Content and Language Integrated English Course for University Students. unpublished master thesis. Soka University.

Sabina, z. (2018). The importance of Teaching listening and speaking skills. World science. 6 (34) June 2018 http://ws-conference.com/

Sadiku, L. (2015). The Importance of Four Skills Reading, Speaking, Writing, Listening in a Lesson Hour. European Journal of Language and Literature Studies. 1 (1)34-45.

Samper, M. (2015). Evaluation of the implementation of CLIL methodology in the Didactics of the English Language in Preschool Education Course Taught in the Preschool Education Teacher Undergraduate program at the university of Alicante. Published Doctoral thesis. University of Alicante School of Education.

Segura, R. (2012). The importance of teaching listening and speaking skills. unpublished master thesis. Matritensis Universitas.

Scarcella, R. C. \& Oxford, R.L. (1994). "Second Language Pronunciation: The State of the Art in Instruction". System. 22 (2) 221-230.

Singh, C; Ja'afar, H; Abdullah, M; Mostafa, N and, Zamri, M (2018) Flipped Classroom Approach for Improving Speaking Skills of TVET Trainees. International Journal of Applied Linguistics \& English Literature 14(1) 22-34.

Thornburry, S. (2018) Forward to Toothbrush and other plays. Gilgimish. UK.

Thornburry, S (2013) The Learning Body in Meaningful Action by Arnold J and Murphey,T (eds); CUP. UK.

Torky, Sh. (2006) The Effectiveness of a Task- Based Instruction program in Developing the English Language Speaking Skills of Secondary Stage Students. Published PhD. Thesis. Ain shams University.

Ulas, A. (2008) Effects of Creative, Educational Drama Activities on Developing Oral Skills in Primary School Children. American Journal of Applied Sciences 5 (7): 876-880,

Wang, W. (2017) Improving Students' Oral Skills Through a Cooperative Learning Approach to Teaching Chinese College English. Published MA thesis. University of Victoria.

Zourob, M. (2014) The Effectiveness of Using Webinar on Improving Speaking Skills for the Rafah UNRWA Seventh Graders and their Anxiety in Speaking. Unpublished master thesis. IUG. 